\title{
COLD CRACKING OF S460N STEEL WELDED IN WATER ENVIRONMENT
}

\author{
Jacek Tomków \\ Jerzy Łabanowski \\ Dariusz Fydrych \\ Grzegorz Rogalski \\ Gdansk University of Technology, Poland
}

\begin{abstract}
This paper shows results of weldability testing of fine-grained high-strength low-alloy S460N steel welded in water environment by covered electrodes. The tests were carried out by using the CTS test specimens with fillet welds. Four specimens were welded under water and one specimen in air. Welded joints were subjected to non-destructive visual and penetration tests. The accepted joints were then subjected to macroscopic and microscopic inspection and Vickers hardness measurements as well. The experiments showed that $S 460 N$ steel welded in water environment is characterized by a high susceptibility to cold cracking.
\end{abstract}

Keywords: underwater welding, wet welding, high-strength low-alloy steel, cold cracking, CTS test

\section{INTRODUCTION}

Development of underwater welding is a result of increasing demand on mineral raw materials. Searching for hydrocarbons resources on sea and ocean bed caused in extensive progress of diving techniques as well as making use of divers in building marine structures. From several dozen years an issue of conducting repair of ocean-engineering and hydro-technical structures has been appeared more and more often. The developing offshore industry demands to make the repairs in water environment, without disassembling the elements and moving them into air [1,2]. The most widely used repair method is wet welding which, for economic reasons, is carried out generally with covered electrodes $[3,4]$. However in wet welding FCAW method is also common used [5]. Despite its common application the method leads to many problems [6,7]. For structural elements working under water high strength steels are more and more widely used. Weldability of these steels in the air is a well investigated issue but transferring the process into water environment still produces many problems $[3,4]$. The joints made by using wet method show presence of welding imperfections such as gas porosity, shape failures and cracks $[8,9]$. The issue most often met is steel susceptibility to cold cracking [10-13]. Water environment significantly intensifies risk of producing such cracks due to the following factors appearing during welding process $[1,14]$ :

- $\quad$ increased cooling rate resulting from fast transfer of heat from outer part of arc and welding area,

- hydrogen concentration resulting from presence of water vapour surrounding welding arc,

- presence of residual stresses,

- $\quad$ increased pressure values, leading to instability of welding arc.

The water environment makes it impossible or difficult to apply many traditional methods for preventing cold cracking, which are successfully used in making welded joints in the air. Out of the methods lowering risk of cold cracking in water environment, the following find application in practice $[3,7,23]$ :

- the increasing of welding heat input, 
- the application (for crucial elements only) of austenitic electrodes whose deposited metal is more ductile,

- the addiction of calcium fluoride to electrode coating which binds hydrogen into a durable compound in welding temperature, decreasing its influence on generating cold cracks.

There is a common opinion that water practically eliminates possible application of preheating to welded joints as well as their further thermal treatment to be performed in a traditional way, that is able to minimize steel susceptibility to cracking. Fast cooling rate unfavourably influences structural transformations, that impairs joint properties [15,16]. Water environment makes the cooling rate faster. However, the latest investigations show that application of heating induction is possible [17]. Research tests on ultrasonic enhancement the underwater welding processes $[18,22]$ or application of temper bead welding technique $[19,24]$ are also carried out. The minimizing of steel susceptibility to cold cracking is especially important in case of higher strength steels. Water contributes to increasing number of imperfections, resulting also in decreasing mechanical properties of welded joints. It results a. o. from diffusion of hydrogen which creates favourable conditions for producing cracks and microcracks lowering the strength of joints $[7,14,20]$. The recent investigations show that even a change in chemical content of electrodes does not eliminate the problem of cold cracking which appear in the joints [12].

For assessment of steel weldability in water environment the self- restraint CTS tests and Tekken tests are used $[1,2,6]$. As underwater welding operations, especially those connected with failure repair, require making fillet joints, the CTS test was selected for the assessment of susceptibility to cold cracking of the $\mathrm{S} 460 \mathrm{~N}$ steel.

\section{EXPERIMENTS AND RESULTS}

The research was aimed at the assessment of weldability of S460N fine-grained steel during wet welding by means of MMA method (111 acc. to ISO 4063). The research program covered conducting CTS tests on five joints in accordance with guidelines of EN ISO 17642-2 standard, four out of which were welded in water environment and one in air. The CTS test belongs to technological self-restraint tests and makes it possible to assess susceptibility to cold cracking in all zones of overlapping joints with fillet welds. Fig. 1 presents the schematic diagram of the specimen in question.

The test specimen was produced of S460N fine-grained high strength steel plate of $12 \mathrm{~mm}$ in thickness. Tab.1 shows the chemical composition of the steel according to a control analysis performed by using spark emission spectrometry. The mechanical properties of the examined steel are presented in Tab. 2.
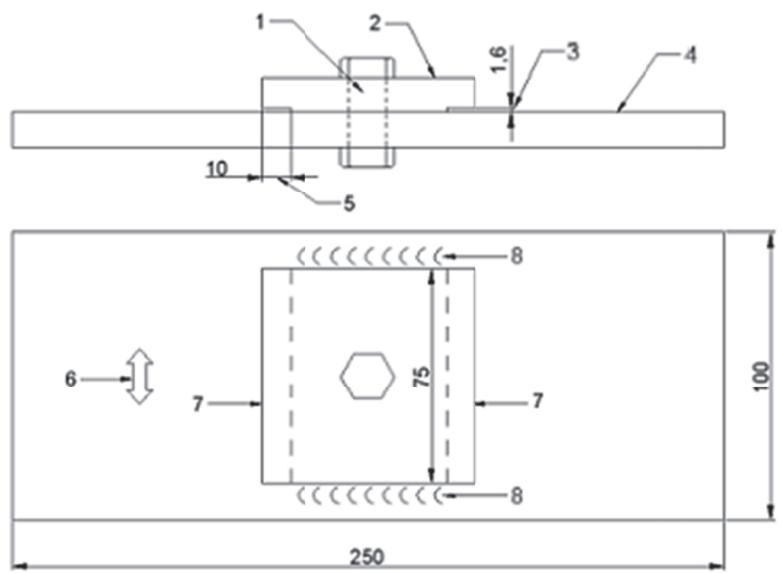

Fig. 1. The schematic diagram and dimensions of the CTS test specimen acc. EN ISO 17642-2 standard; 1 - clearance hole of $13 \mathrm{~mm}$ diameter; 2- top plate; 3-root notch gap; 4- bottom plate; 5-root notch depth; 6-preferred principal rolling direction; 7-test welds; 8- anchor welds

Tab. 1. Chemical composition of S460N steel

\begin{tabular}{|c|c|c|c|c|c|c|c|c|c|c|c|}
\hline \multicolumn{12}{|c|}{ Element content, $\%$} \\
\hline & $u$ & $\vec{\omega}$ & $\sum_{\Sigma}^{\xi}$ & a & $\dot{U}$ & $\stackrel{0}{\Sigma}$ & $\ddot{z}$ & 飞 & $\tilde{J}$ & $>$ & $u^{e^{\frac{\omega}{2}}}$ \\
\hline 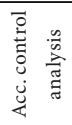 & \begin{tabular}{l}
0 \\
\hdashline \\
0
\end{tabular} & ח̂? & $\stackrel{\text { nִ }}{-}$ & $\begin{array}{l}\widetilde{\sigma} \\
\text { o. }\end{array}$ & $\stackrel{\hat{0}}{\circ}$ & $\stackrel{m}{0}$ & $\stackrel{n}{2}$ & $\begin{array}{l}\text { } \\
0 \\
0\end{array}$ & $\stackrel{m}{0}$ & $\begin{array}{l}\hat{o} \\
\text { o }\end{array}$ & $\begin{array}{l}\text { t' } \\
+ \\
0\end{array}$ \\
\hline
\end{tabular}

$\mathrm{Ce}_{\mathrm{MIS}}=\mathrm{C}+(\mathrm{Cr}+\mathrm{Mo}+\mathrm{V}) / 5+(\mathrm{Cu}+\mathrm{Ni}) / 15$

Tab. 2. Mechanical properties of S460N steel

\begin{tabular}{|c|c|c|}
\hline Yield point $\mathrm{R}_{\mathrm{e}}, \mathrm{MPa}$ & $\begin{array}{c}\text { Ultimate tensile } \\
\text { strength } \mathrm{R}_{\mathrm{m}}, \mathrm{MPa}\end{array}$ & Elongation $\mathrm{A}, \%$ \\
\hline 511 & 626 & 27.3 \\
\hline
\end{tabular}

The welding operation was carried out in water environment at the water depth of $150 \mathrm{~mm}$ by using the underwater test stand (Fig. 2) of the Laboratory of Welding Engineering in Gdańsk University of Technology.

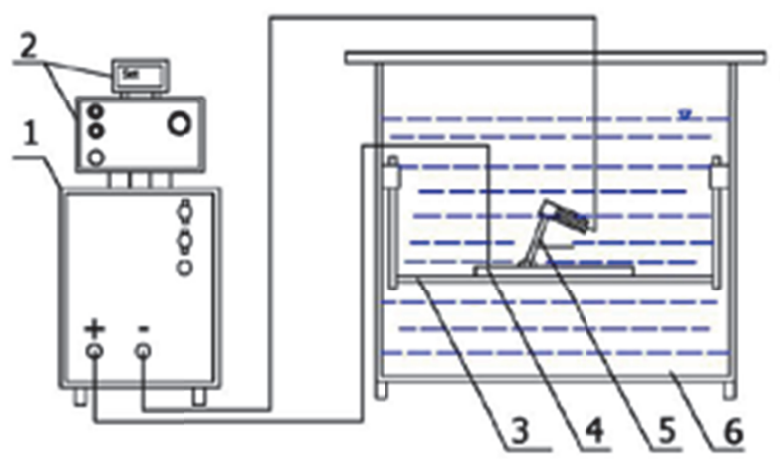

Fig 2. The schematic diagram of the underwater welding at small depth: 1-power source, 2-control panel and wire feeder, 3-table, 4-welded plate, 5covered electrode and electrode holder, 6- tank 
The anchor welds and test welds were made with the use of OMNIA (ISO 2560-A: E 380 R 11) commercial rutile electrodes of $4 \mathrm{~mm}$ diameter, intended for welding in all positions. The electrodes were selected based on the fact that they ensure good plastic properties of deposited material in order to minimize possible generation of cracks. The chemical composition and mechanical properties of the applied electrodes are given in Tab. 3.

Tab. 3. Chemical composition (wt \%) and mechanical properties of Omnia covered rutile electrodes [26]

\begin{tabular}{|l|l|l|l|l|l|}
\hline \multicolumn{2}{|l|}{ Chemical composition, wt \% } & \multicolumn{4}{l|}{$\begin{array}{l}\text { Mechanical properties of } \\
\text { deposited material }\end{array}$} \\
\hline C & $\mathrm{Mn}$ & $\mathrm{Si}$ & $\mathrm{Re}, \mathrm{MPa}$ & $\mathrm{Rm}, \mathrm{MPa}$ & $\mathrm{A}, \%$ \\
\hline 0.07 & 0.55 & 0.44 & 503 & 538 & 26 \\
\hline
\end{tabular}

The CTS specimens were marked by using the test name and subsequent arabic digits. The welding was carried out with the constant DC- polarity in compliance with producer's recommendations. The welding process parameters are presented in Tab. 4

Tab. 4. Welding parameters of CTS tests

\begin{tabular}{|c|c|c|c|c|c|c|c|c|}
\hline & \multicolumn{4}{|c|}{ Weld I } & \multicolumn{4}{|c|}{ Weld II } \\
\hline 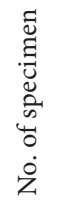 & 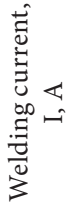 & 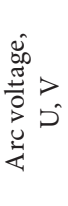 & 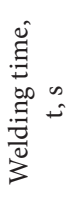 & 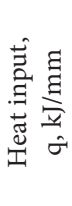 & 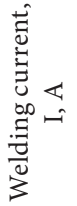 & 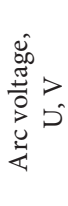 & 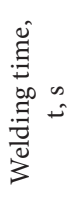 & 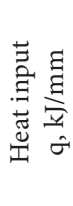 \\
\hline \multicolumn{9}{|c|}{ Welded under water } \\
\hline W1 & 192 & 25.8 & 18.7 & 1.04 & 196 & 24.5 & 17.2 & 1.10 \\
\hline W2 & 192 & 25.5 & 17.9 & 1.22 & 196 & 24.8 & 12.9 & 0.84 \\
\hline W3 & 184 & 25.8 & 20.1 & 1.27 & 188 & 25.0 & 16.6 & 0.98 \\
\hline W4 & 188 & 25.5 & 17.1 & 1.05 & 184 & 22.3 & 15.9 & 0.91 \\
\hline \multicolumn{9}{|c|}{ Welded in air } \\
\hline P5 & 181 & 23.4 & 21.1 & 1.19 & 178 & 24.1 & 17.9 & 1.03 \\
\hline
\end{tabular}

The prepared specimens were subjected to non-destructive tests after $72 \mathrm{~h}$ from the end of welding operation. The visual and penetration tests were conducted in compliance with the standards EN ISO 17637 (VT) and EN ISO 3452-1 (PT). In the case of the specimens welded under the water, weld imperfections were observed in one weld of the specimen 2 (insufficient weld thickness, incompletely filled groove, incomplete fusion) as well as in two welds of the specimen 4 (in the first - laid weld: insufficient weld thickness, lack of fusion; in the second-laid weld: undercuts, incomplete fusion, insufficient weld thickness, spattering). The joints were qualified unacceptable. In the case of the specimen welded in air, cracks were observed in crater pipe, which did not excluded the joints from further tests. In the visual tests (VT) the welds complying with the quality level B acc. EN ISO 7637 standard were acceptable. In the penetration tests the welds complying with the quality level 2X acc. EN ISO 3452-1 standard were considered acceptable. Fig. 3 presents example results of the non-destructive tests in question.

a)

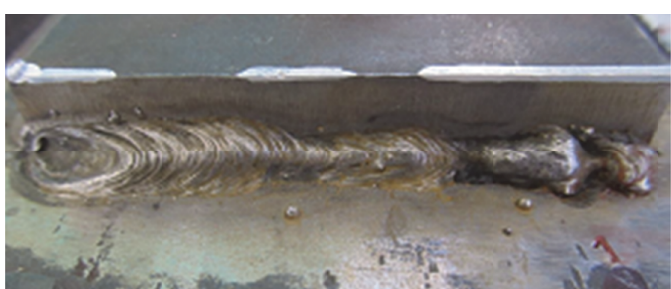

b)

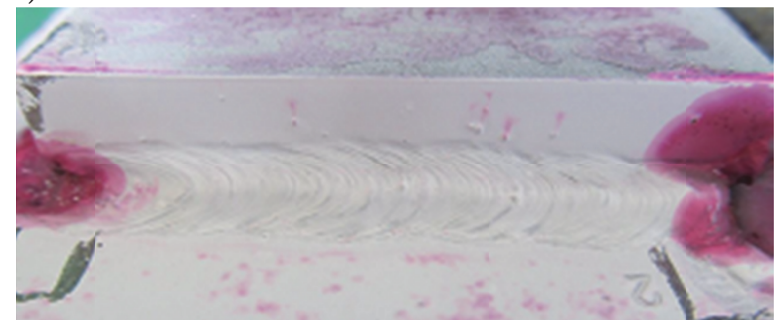

Fig. 3. Results of non-destructive testing of S460N steel joints; a) VT, the specimen W2, the first-laid weld: incompletely filled groove, incomplete fusion; b) PT, the specimen $W 1$ : no imperfections.

\section{MACROSCOPIC METALLOGRAPHIC TESTS}

The metallographic tests were carried out in acc.to guidelines of EN ISO 17639 standard - after etching the specimens with $4 \%$ Nital. The macroscopic tests of CTS specimens welded in water environment revealed imperfections such as gas pores and cracks. The welds made in air did not have imperfections. Fig. 4 presents example results of the macroscopic tests.

a)

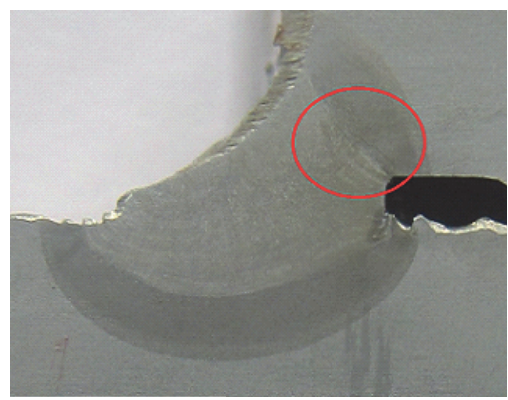

b)

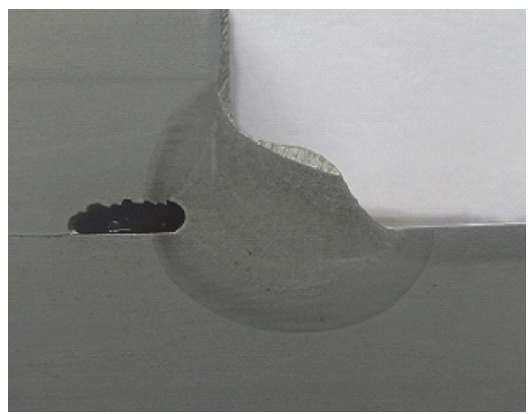

Fig. 4. Pictures illustrating results of the macroscopic testing of S460N steel; a) the specimen W3.1: cracks along fusion line and in HAZ; b) the specimen P5.1: no imperfections. Etching: Nital 


\section{MICROSCOPIC METALLOGRAPHIC TESTS}

As a result of the performed microscopic tests it was stated that the structure of $\mathrm{S} 460 \mathrm{~N}$ steel is composed of fine-grained pearlite as well as fine-grained ferrite with layers. HAZ has brittle structures characteristic for joints made in fast cooling rate conditions. Cracks was revealed in all the specimens welded in the water. They were placed in the welds, HAZ as well as fusion line along $65-75 \%$ of its length. During examining the specimen welded in air no cracks were found. Fig. 5 presents the results of microscopic tests of S460N steel.

a)

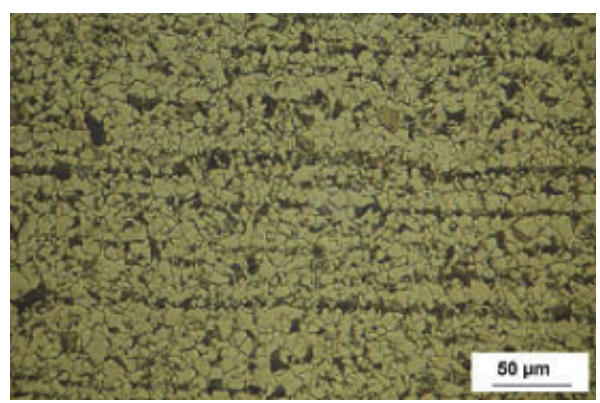

b)

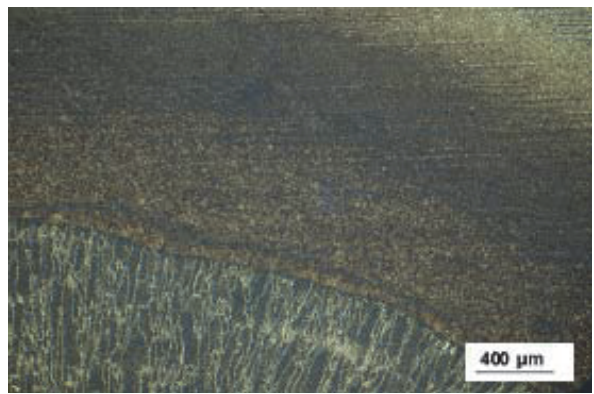

c)

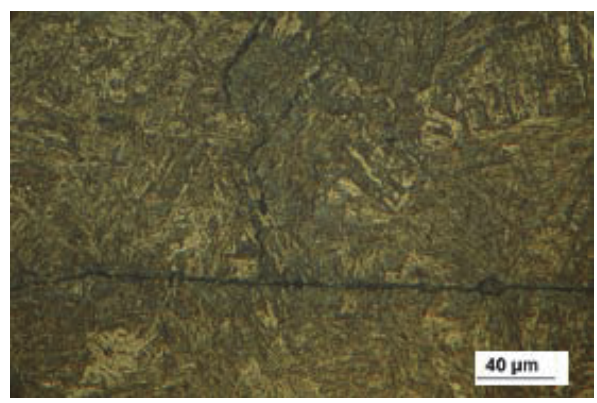

d)

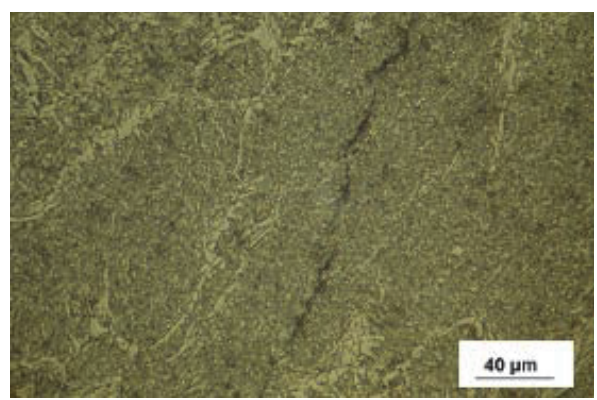

Fig. 5. Results of the microscopic testing of S460N steel joints welded under water; a) base material, magn. 400x; b) cracks in HAZ, magn. 50x; c) cracks in HAZ, magn. 500x; d) cracks in weld, magn. 500x. Etching: Nital

\section{HARDNESS MEASUREMENTS}

The Vickers hardness measurements under $98 \mathrm{~N}$ load (HV10) along the line placed $2 \mathrm{~mm}$ below weld face were made in compliance with the requirements of PN-EN ISO 9015-1:2011 standard. Fig. 6 presents the schematic layout diagram of measurement points. Fig. 7 shows example results of hardness measurements for the $\mathrm{S} 460 \mathrm{~N}$ steel specimens. The maximum values of hardness in HAZ of the tested CTS joints welded in water environment were equal to around $500 \mathrm{HV} 10$, reaching its very maximum of $508 \mathrm{HV} 10$ in the specimen W3. In the case of the specimen P5 welded in air the maximum hardness reached $468 \mathrm{HV} 10$. For S460N steel the limit hardness value of $380 \mathrm{HV} 10$ was assumed according to the PN-EN ISO 15614-1:2008 standard. Tab. 5 shows results of hardness measurements in the form of maximum values found in HAZ of particular joints.

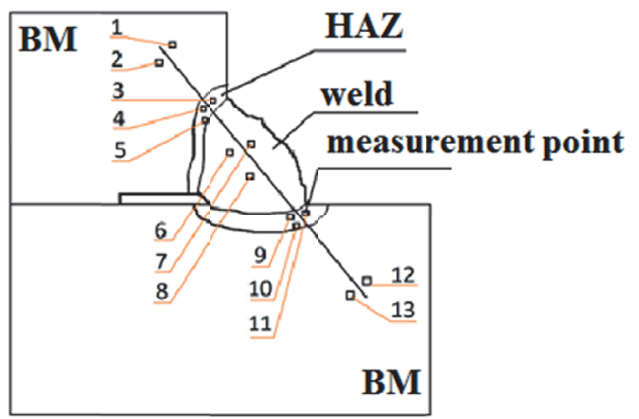

Fig. 6. Schematic layout of hardness testing points - CTS test

a)

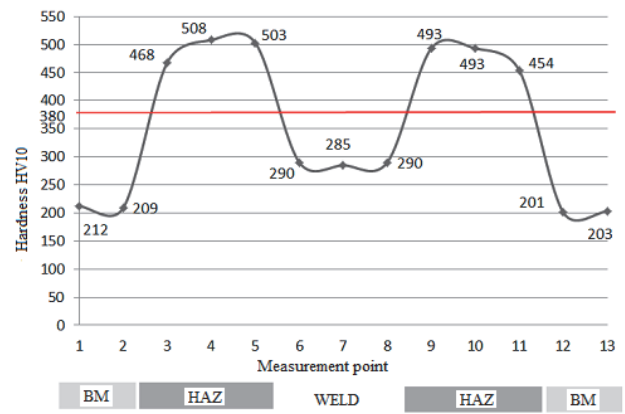

b)

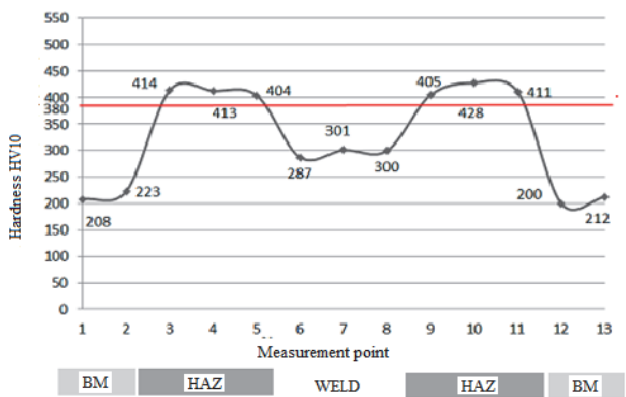

Fig. 7. Results of hardness measurements for S460N steel; a) hardness distribution across W3 (first-laid weld) joint welded underwater HV10max=508; b) hardness distribution across P5 (first-laid weld) joint welded underwater, HV10 max $=414$ 
Tab. 5. Results of hardness tests

\begin{tabular}{|l|l|}
\hline \multicolumn{1}{|c|}{ No. of specimen } & \multicolumn{1}{c|}{$\begin{array}{c}\text { Maximum value of } \\
\text { HV10 }\end{array}$} \\
\hline \multicolumn{2}{|c|}{ Specimens welded underwater } \\
\hline W1 & 503 \\
\hline W2 & 500 \\
\hline W3 & 508 \\
\hline W4 & 525 \\
\hline \multicolumn{2}{|c|}{ The specimen welded in air } \\
\hline P5 & 433 \\
\hline
\end{tabular}

\section{SUMMARY}

Weldability tests of S460N high strength steel $12 \mathrm{~mm}$ plate specimens welded with covered electrodes in water environment using wet method and in air were performed. The welding process involved many problems - welding arc was burning instable that made forming correct welds difficult. In joints made of the tested steel many cracks located both in the weld and HAZ were found. The microscopic tests revealed that the cracks run along $65-75 \%$ fusion line. In the case of joints welded in air environment no imperfections were found. Results of Vickers hardness measurements (HV10) demonstrated that all the specimens welded under water had the hardness value reaching 525 HV10. It contributes to forming cold cracks such as those found during the other tests. None of the tested joints will satisfy the assumed hardness criterion according to EN ISO 15614-1 standard (380 HV10) for the tested steel. One of the ways of lowering the hardness of welded joints made of a high strength steel in water environment may be application of the temper bead welding technique [25]. The other way to improve the quality of joints made in water environment is friction taper welding [27-29].

Haring regard to the value of $\mathrm{S} 460 \mathrm{~N}$ steel carbon equivalent, welding conditions favouring the increase of steel tendency to cold cracking and experience $[3,4,8,19,24]$ it should be recognized, that presented results are justified

\section{CONCLUSIONS}

1. Based on the results of the technological weldability tests of S460N high strength steel it may be stated that CTS welded joints made under water by using covered electrodes (rutile) in wet conditions are characterized by a high susceptibility to cold cracking.

2. The underwater wet welding using covered electrodes resulted in a significant increase of hardness of the HAZ of welded joints up to $525 \mathrm{HV} 10$ (in the specimen W4). All of the specimens made under water and made in air do not satisfy the acceptance criterion acc. EN ISO 15614-1 standard.

3. It is recommended to perform weldability tests of the butt-welded joints (Tekken test) as well as to conduct a research aimed at the improvement of $S 460 \mathrm{~N}$ steel weldability in water environment.

\section{REFERENCES}

1. Wang, J., Sun, Q., Jiang, Y., Zhang, T., Ma, J., \& Feng, J.: Analysis and improvement of underwater wet welding process stability with static mechanical constraint support. Journal of Manufacturing Processes, 34 (2018), pp. 238-250.

2. Hu Y., Shi YH., Shen XQ., Wang ZM.: Microstructure, pitting corrosion resistance and impact toughness of duplex stainless steel underwater dry hyperbaric Flux-Cored Arc. Materials, 10 (12) (2018), pp. 1443.

3. Fydrych D., Łabanowski J., Tomków J., Rogalski G.: Cold cracking of underwater wet welded S355G10+N high strength steel. Advances in Materials Science, Vol. 16., iss. 3 (2015), pp. $48-56$

4. Fydrych D., Łabanowski J., Rogalski G.: Weldability of high strength steels in wet welding conditions. Polish Maritime Research, 2 (2013), pp. 67-73.

5. Świerczyńska A., Fydrych D., Rogalski G.: Diffusible hydrogen management in underwater wet self-shielded flux cored arc welding. International Journal of Hydrogen Energy, 42(38) (2017), pp. 24532-24540.

6. Li HL., Liu D., Song YY., Yan YT., Guo N., Feng JC.: Microstructure and mechanical properties of underwater wet welded high carbon-equivalent steel Q460 using austenitic consumables. Journal of Materials Processing Technology, 249 (2017), pp. 149-157.

7. Santos V. R., Monteiro M. J., Rizzo F.C., Bracarense A. Q., Pessoa E. C. P., Marinho R. R., Vieira L. A.: Development of an oxyrutile electrode for wet welding. Welding Journal, 91(2012), pp. 319-328.

8. Garašić I., Krajl S., Kožuh S.: Investigation into cold cracking in underwater wet welding of API5L X70 steel. Transactions of FAMENA, 3 (2009), pp. 25-34.

9. Maksimov S. Yu.: Underwater arc welding of higher strength low-alloy steels. Welding International Vol. 24, Iss. 6 (2010), pp. 449-454.

10. Rogalski G., Łabanowski J., Fydrych D., Tomków J.: Beadon-plate welding on S235JR steel by underwater local dry chamber process. Polish Maritime Research, 21 (2014), pp. 58-64.

11. Kannengiesser T., Boellinghaus T.: Cold cracking tests- an overview of present technologies and applications. Welding in the World, 1 (2013), pp. 3-37. 
12. Kurji R., Coniglio N.: Towards the establishment of weldability test standards for hydrogen-assisted cold cracking. The International Journal of Advanced Manufacturing Technology, 77 (2015), pp. 1581-1597.

13. Chen H., Guo N., Shi X., Du Y., Feng J., Wang G.: Effect of hydrostatic pressure on protective bubble characteristic and weld quality in underwater flux-cored wire wet welding. Journal of Materials Processing Technology, 259 (2018), 159-168.

14. Guo N., Liu D., Guo W., Li H., Feng J.: Effect of Ni on microstructure and mechanical properties of underwater wet welding joint. Materials \& Design, 77 (2015), pp. 25-31.

15. Sajek A., Nowacki J.: Comparative evaluation of various experimental and numerical simulation methods for determination of $t 8 / 5$ cooling times in HPAW process weldments. Archives of Civil and Mechanical Engineering, 18(2) (2018), pp. 583-591.

16. Górka J.: Microstructure and properties of high-temperature (HAZ) of thermos-mechanically treated S700MC highyield-strength steel. Materiali Tehnologije/Materials Technologies, 50 (4) (2016), pp. 617-621.

17. Gao W.B., Wang D.P., Cheng F.J., Deng C.Y., Xu W.: Underwater wet welding for HSLA steels: chemical composition, defects, microstructures, and mechanical properties. Acta Metallurgica Sinica (English Letters), 9 (2015), pp. 1097-1108.

18. Gao W., Wang D., Cheng F., Di X., Xu W.: Micro-structural and mechanical performance of underwater wet welded S355 steel. Journal of Materials Processing Technology, 238 (2016), pp. 333-340.

19. Fydrych D., Świerczyńska A., Rogalski G., Łabanowski J.: Temper bead welding of S420G2+M steel in water environment. Advances in Materials Science, Vol. 16, iss. 4 (2016), pp. 5-16.

20. Zhang H.T., Dai X.Y., Feng J.C., Hu L.L.: Preliminary investigation on real-time induction heating-assisted underwater wet welding. Welding Journal, 1 (2015), pp. 8-15.

21. Gao W., Wang D., Cheng F., Deng C., Liu Y., Xu W.: Enhancement of the fatigue strength of underwater wet welds by grinding and ultrasonic impact treatment. Journal of Materials Processing Technology, 223 (2015), pp. 305-312.

22. Sun Q.J., Cheng W.Q., Liu Y.B., Wang J.F., Cai C.W., Feng J.C.: Microstructure and mechanical properties of ultrasonic assisted underwater wet welding joints. Materials \& Design, 103 (2016), pp. 63-70.
23. Fydrych D., Świerczyńska A., Rogalski G.: Effect of underwater wet welding conditions on the diffusible hydrogen content in deposited metal. Metallurgia Italiana, 11/12 (2015), pp. 47-52.

24. Tomków J., Rogalski G., Fydrych D., Łabanowski J.: Improvement of $S 355 G 10+N$ steel weldability in water environment by Temper Bead Welding. Journal of Materials Processing Technology, 262 (2018), pp. 375-381.

25. Tomków J., Fydrych D., Rogalski G., Łabanowski J.: Temper bead welding of $S 460 \mathrm{~N}$ steel in wet welding conditions. Advances in materials science, 3 (2018), pp. 5-13.

26. http://www.lincolnelectric.com/plpl/Consumables/ Pages/product.aspx?product=Products_ConsumableEU_ StickElectrodes-Omnia-Omnia(LincolnElectric_EU_Base)

27. Xiong J., Yang X., Lin W., Liu K.: Effects of welding parameters on microstructure and mechanical properties of underwater wet friction taper plug welded pipeline steel. Welding in the World, (2018), pp. 1-12.

28. Xu Y.C., Jing H.Y., Han Y.D., Xu L.D.: Microstructures and mechanical properties od friction tapered stud overlap welding for X65 pipeline steel under wet conditions. Journal of Materials Engineering and Performance, 26(8) (2017), pp. 4092-4103.

29. Wang F, Yang X., Yin Y., Cui L.: Thermal process influence on microstructure and mechanical behavior for friction taper plug welding in structural steel S355. The International Journal of Advanced Manufacturing Technology, 88(9-12) (2017), pp. 3459-3466.

\title{
CONTACT WITH THE AUTHOR
}

\author{
Jacek Tomków \\ e-mail: jacek.tomkow@pg.edu.pl \\ Gdańsk University of Technology \\ 11/12 Narutowicza St. \\ 80 - 233 Gdańsk \\ Poland
}

